\title{
Social Health Promotion and Equity in Vulnerable Populations
}

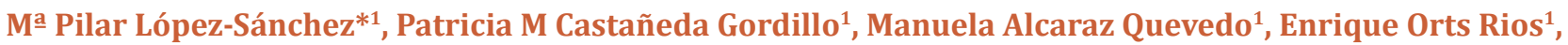 \\ Marta Asensi Girbes ${ }^{2}$ and Enrique Asensi Martin² \\ ${ }^{1}$ Public Health centre of València. València, Spain \\ ${ }^{2}$ Association for Cooperation between Communities, València, Spain
}

Submission: July 06, 2018; Published: July 12, 2018

*Corresponding author: Mํㅗ Pilar López-Sánchez, Public Health centre of València, Street Democracia, 77, 46018 València, Spain, Email: lopez_pilsan@gva.es

\begin{abstract}
Mihsalud (women, childhood and men building health) is a programme aimed at health promoting in vulnerable populations. Promoted by the Public Health Centre of València in collaboration with other Health Centres, the València City Council, the Association for Cooperation between Communities (ACOEC) and a group of other associations in the city. Mihsalud is a social mobilization and high dissemination programme for promoting health and access to health services for populations being in situations of vulnerability in the city València. The programme responds to the objectives related to the reduction of inequalities described in the document Health 2020 through the World Health Organization, together with the València Region Health Plan and our Regional Public Health Services Portfolio development: Training community health workers that promote health among their peers and work in coordination with health professionals. The program includes criteria of innovation, gender and interculturality.
\end{abstract}

Keywords: Health promotion; Vulnerable populations; Interculturality; Community health workers; Participation; Public health

\section{Mini Review}

Mihsalud [1] (women, childhood and men building health) is a programme aimed at health promoting in vulnerable populations and a social mobilization and high dissemination programme for promoting health and access to health services for populations being in situations of vulnerability in the València city. Mihsalud has based on the health assets model [2,3], the peer education methodology [4,5] and the commission to reduce social inequalities in health [6]. Since 2007, mihsalud has been trying to promote a bigger participation, and implication of the associations as agents for change, in order to promote health, not only in their social background but also in the territory where they are settled. The associations are intended to be turned into the main protagonists of actions in favour of health, equality and inequality reduction. Promoted by the Public Health Centre of València in collaboration

Table 1: Activities carried out in the mihsalud programme. with other health centres, the València City Council, ACOEC and a group of other associations in the city. The objective is to promote health, especially sexual and reproductive health, preventing gender-based violence and improving access to health programs and services for people in situations of social vulnerability València city (native population, ethnic minorities and immigrants). The territorial action is the Basic Health Zones of the Health Departments of the València city (València Clínico-Malvarrosa, Valèn cia-La Fe, València-Dr Peset and València-General Hospital). The methodology is based on coordination and participation with associations [7] and vulnerable population groups to train community leaders as Community Health Workers[5], to promote a network in urban environments by contacting health professionals in primary care, public health and municipal services to promote integration and social cohesion in València city (Table 1).

Community Health Workers training through the Training-Action courses, Health Education among young people and Complementary Training

Health professionals training with community health courses and workshops with the health assets methodology, equity promotion health, to attention diversity and cross cultural

Mihsalud, creates an intercultural mediation environment in health through the Community Health Workers and health professionals of the Basic Health Zones and departments

It encourages and connects associations to incorporate health promotion into their program [8] and creates a monthly meeting space (Community Forum $2^{\text {nd }}$ Tuesday Health) [9], at the Immigration Support Centre of València City Council, where health issues are addressed proposed by them 
Public Health Centre of València and the ACOEC coordinate and develope mihsalud city project financed through the València City Council and the financial foundation social work (Obra Social La Caixa)

\section{Results}

a. Through mihsalud programme, more than 10290 people have been mobilized.

b. The mihsalud programme developed an asset map of the València city.

c. There have been 82 monthly forums with an average participation: 12 associations and 18 assistants (from Africa, South America and Europe).

d. 180 Community Health Workers have been trained (143 women and 37 men) in 9 editions of the Training-Action Course, belonging to 72 associations, with an average of 20 Community Health Workers and 33 different nationalities (Spain 40\%, Bolivia 15'8\% and Colombia 12'4\%) by course.

e. In 2016, the project City mihsalud included 31 workshops (358 attendees), 32 community leaders, 45 information points and 731 informal conversations (454 women and 277 men).

f. In 2016 Mihsalud obtained the Dr. Joan Peset Aleixandre Scholarship (València Medical Institute and València City Council).

g. Mihsalud programme was recognized in 2015 by the Health Ministry, Social Services and Equality as "Good practice of the National Health System in the strategy of delivery care and reproductive health."

h. In 2018 it has been recognized as good practices in the València Health System by the Generalitat Valenciana.

i. The programme meets innovation criteria, intersectoriality, equity, gender, intercultural and social participation.

\section{Authors' Information}

This article being part of articles compendium of the doctoral thesis in Clinical Nursing of the University of València.

\section{References}

1. Paredes Carbonell JJ, Alcaraz M, López P (2012) MIHSALUD. Una experiencia de dinamización comunitaria con población inmigrante de la ciudad de Valencia. Comunidad 14: 29-32.

2. Cofiño R, Aviño D, Belén Benedé C, BlancaBotello, JaraCubillo, et al. (2016) Promoción de la salud basada en activos: ¿cómo trabajar con esta perspectiva en intervenciones locales? Gac Sanit 30(Supplement 1): 93-98.

3. Sánchez Casado L, Paredes Carbonell JJ, López Sánchez P, Morgan A (2017) Mapa de activos para la salud y la convivencia. Propuesta de acción desde la intersectorialidad. Index de Enfermería 26(3): 180184.

4. (2005) Youth Peer Education Toolkit. Standards for Peer Education Programmes. United Nations Population Fund.

5. López Sánchez P, Paredes-Carbonell JJ, Alcaraz Quevedo M (2013) Rediseñando la formación-acción de agentes de salud de base comunitaria. Index de Enfermería 22(3): 166-70.

6. (2010) Comision para Reducir las Desigualdades Sociales en Salud en España: Avanzando hacia la equidad: propuesta de políticas y de intervenciones para reducir las desigualdades sociales en salud en España. Madrid: Ministerio de Sanidad y Politica Social.

7. López Sánchez P, Paredes Carbonell JJ, Cassetti V (2018) Cambios atribuidos a un programa basado en la formación-acción de agentes de salud ¿Qué dicen las asociaciones?. Rev Esp Salud Publica.

8. Castro Rojas L, Crisanto Pantoja M, Martín Garcia A (2016) Salud en nuestra agenda: guía para impulsar acciones comunitarias en salud desde las asociaciones. Valencia: Generalitat Valenciana p. 90.

9. López Sánchez P, Paredes Carbonell JJ, Grau Camarena C (2017) Foro comunitario $2^{2}$ martes salud, una herramienta de promoción de salud comunitaria. RIdEC Revista de la Asociación de Enfermería Comunitaria 10(1): 17-21.

\section{Your next submission with Juniper Publishers will reach you the below assets}

- Quality Editorial service

- Swift Peer Review

- Reprints availability

- E-prints Service

- Manuscript Podcast for convenient understanding

- Global attainment for your research

- Manuscript accessibility in different formats

( Pdf, E-pub, Full Text, Audio)

- Unceasing customer service

\section{Track the below URL for one-step submission}

https://juniperpublishers.com/online-submission.php 